IZA DP No. 8595

Mapping and Understanding Ethnic Disparities in

Length of Schooling: The Case of Ningxia

Autonomous Region, China

Björn Gustafsson

Ding Sai

October 2014 


\title{
Mapping and Understanding Ethnic Disparities in Length of Schooling: The Case of Ningxia Autonomous Region, China
}

\author{
Björn Gustafsson \\ Göteborg University and IZA \\ Ding Sai \\ Chinese Academy of Social Sciences
}

Discussion Paper No. 8595

October 2014

\author{
IZA \\ P.O. Box 7240 \\ 53072 Bonn \\ Germany \\ Phone: +49-228-3894-0 \\ Fax: +49-228-3894-180 \\ E-mail: iza@iza.org
}

\begin{abstract}
Any opinions expressed here are those of the author(s) and not those of IZA. Research published in this series may include views on policy, but the institute itself takes no institutional policy positions. The IZA research network is committed to the IZA Guiding Principles of Research Integrity.

The Institute for the Study of Labor (IZA) in Bonn is a local and virtual international research center and a place of communication between science, politics and business. IZA is an independent nonprofit organization supported by Deutsche Post Foundation. The center is associated with the University of Bonn and offers a stimulating research environment through its international network, workshops and conferences, data service, project support, research visits and doctoral program. IZA engages in (i) original and internationally competitive research in all fields of labor economics, (ii) development of policy concepts, and (iii) dissemination of research results and concepts to the interested public.
\end{abstract}

IZA Discussion Papers often represent preliminary work and are circulated to encourage discussion. Citation of such a paper should account for its provisional character. A revised version may be available directly from the author. 
IZA Discussion Paper No. 8595

October 2014

\section{ABSTRACT}

\section{Mapping and Understanding Ethnic Disparities in Length of Schooling: The Case of Ningxia Autonomous Region, China}

Disparities in length of schooling between the largest Muslim minority in China, the Hui, and the Han majority are investigated. We use household data collected in Ningxia autonomous region in 2007. It is found that compared with Han persons of the same age and gender, Hui persons have shorter educations with the exception of young and middle-aged urban males who have twelve years of schooling, on average. Particularly noteworthy is that as many as 45 percent of adult rural Hui females are not literate. Possible reasons for the shorter educations of Hui in many segments of the population are numerous. We show that the incentive to invest in length of schooling is smaller among Hui than Han as the association between education and income is weaker. We also report that Hui parents spend fewer resources on education than Han parents and that fewer years of schooling for Hui in the first generation helps to explain why Hui persons in the second generation have shorter educations.

JEL Classification: $\quad$ 124, J15, P35

Keywords: China, schooling, Hui ethnicity, Han ethnicity, Ningxia, inequality

Corresponding author:

Björn Gustafsson

Department of Social Work

Göteborg University

P.O. Box 720

SE 40530 Göteborg

Sweden

E-mail: Bjorn.Gustafsson@socwork.gu.se 


\section{Introduction}

This paper investigates disparities in years of schooling in China among adults and teenagers between the Hui, China's largest Muslim majority, and the Han majority. Years of schooling is an important factor determining a person's well-being. Persons with longer educations typically earn higher incomes than those with shorter educations, thus they are able to consume more. Furthermore, persons with longer educations are often healthier than their peers with short educations and typically have better prerequisites for taking part in social and political activities. In China it is generally perceived that the Hui have shorter educations than the Han majority, but the detailed pattern is not known. For example it is unknown whether the gap has narrowed or increased over time nor are the reasons for the gap fully understood.

Researchers have studied minority education in China by asking different questions and using an assortment of methods, leading to various insights. ${ }^{1}$ For example, information and opinions can be obtained from students, parents, teachers, school administrators, potential employers and policy-makers and then analysed by the researcher. Activities in classrooms can be observed; schoolbooks, curricula and policy documents can be read and studied. This paper takes yet another approach. We have been involved in collecting a unique household survey conducted in rural as well as urban areas of Ningxia Hui autonomous region and here we report findings from having analysed the data.

In much of the paper we investigate length of schooling for persons who have reached an age where they can be supposed to have completed their educations. In addition we study length of schooling among the parents of these adults and school enrolment among teenagers. As

\footnotetext{
${ }^{1}$ For an overview of the research on education of minority groups in China see Postiglione (2009).
} 
circumstances differ greatly between rural and urban areas of China and often between males and females, we consider such divisions in the analyses. Particularly we ask whether ethnic differences in years of education have decreased across birth cohorts as education has expanded in China. In addition to investigate this hypothesis the paper also aims to throw new light on reasons for the differences in years of schooling between Hui and Han. We do this by analysing if incentives to invest in length of schooling are lower among Hui than Han by estimating income functions. Furthermore we study whether Hui parents spend less on education than Han parents, as well as by investigating the importance of links in length of schooling between parents and children. This makes it possible to answer the question: How much of an educational disadvantage for an adult Hui is due to his or her parents possessing shorter educations than Han parents?

Turning to results, our study documents that Hui individuals in most cases have shorter educations than Han. The exception is that among young and middle-aged urban males, Hui have educations as long (on average twelve years of schooling) as Han of the same gender and age. Of particular note is that as many as 45 percent of adult rural Hui females are not literate. Possible reasons for the shorter educations of Hui in many segments of the population are numerous; these include lover incentives to invest in length of schooling as the association between length of education and income is weaker among Hui than among Han. Furthermore we report that Hui parents are spending fewer resources on education than Han parents and also that fewer years of schooling of Hui in the first generation helps explain why Hui persons in the second generation have shorter educations than Han.

The rest of the paper is laid out as follows: The next section discusses possible reasons for ethnic dispersions in length of schooling in China. Section 3 provides background information 
for the study by describing the Hui ethnic group as well as the autonomous region of Ningxia. The survey we work with is the topic for Section 4 where we use it to present some facts on the two ethnic groups. Section 5 describes differences in length of schooling among adults in Ningxia and how they vary along several dimensions. Section 6 reports information on years of schooling among parents to adults as well as ethnic differences in enrolment among teenagers. In Section 7 we investigate if the association between years of education and income is weaker among Hui than among Han. Section 8 analyses expenditures on education among Hui and Han parents. Section 9 investigates the intergenerational link in length of schooling. Finally we sum up the findings in the concluding section.

\section{Ethnicity and length of schooling in China}

Not much research has been done on dispersions in years of schooling by ethnicity in China based on statistical data. Surveys by Hannum et al (2008) and Hannum and Wang (2012) indicate that although minority persons belonging to later birth cohorts are much better educated than older cohorts, for most minority groups they are at a disadvantage compared to their majority peers.

Many circumstances can have contributed to ethnic gaps in length of schooling in China. Reasons can most likely be traced to circumstances such as quality of schooling and to financial difficulties among parents for paying educational expenditures. Furthermore the opportunity costs for going to school are often higher for ethnic minorities as parents within this group cannot afford to forego potential labour income of children to the same extent as more well-off majority parents. There are also differences in tradition of sending children to 
school which can have to do with differences in cultures and values between ethnic minorities and the majority. Yet another reason, which can be interrelated to the previous reason, is that the payoff from formal education can be lower for ethnic minorities. We will discuss each of these possible explanations at some length. However, please note that government policies and their implementation also have a role to play. Certain measures can give ethnic minority children and youth in China preferred treatment in many cases (Wang, 2007, Teng and Ma, 2009). For example, a Hui youth living in a mountainous region of Ningxia can be admitted to university with 30 fewer points in the university examination than a majority youth (Ningxia Daily, 2012, May 6).

School quality is often lower in schools attended by ethnic minorities in China than in schools attended by the majority, thereby making transitions to longer educations more difficult. China's minorities are concentrated to low-income areas where financial difficulties render a lower school quality. Working in the same direction, instruction in Chinese schools is predominantly in the Mandarin language which is not the first language for many minorities. However, this is not an obstacle for Hui schoolchildren as they use the same language as the ethnic majority.

Length of schooling is also an outcome of choice which often is influenced by culture. There is a long tradition among Hui parents for sending their children when aged six to seven to a religious educational institution (Madrasa) to learn to read the Quran, and for sending them again after graduation from junior middle school at age 15 or $16 .^{2}$ This practise is important for transmitting their ethnic identity to the new generation. However, it is difficult to judge if

\footnotetext{
${ }^{2}$ For the former see Li and Wang (2003) and for the latter Ma (2006). See also Bai et al (2006) and Matsumato and Shimbo (2011).
} 
and to what extent such education function as a complement or substitute to formal schooling. The Hui culture is not known for putting a high value on formal education. For example, rural Hui girls grow up in a social environment where many of their relatives and friends marry early and thereafter assume the main responsibility for housework. In contrast in the majority population of China there is a long tradition of putting a high value on the education provided by the state. .

Among persons with long schooling those who belong to an ethnic minority can find it more difficult to obtain a well-paid job than majority persons. Reasons for this can be not having access to a network when searching for a job and/or the possible existence of discrimination in the job-hiring process. To the extent that barriers exist for ethnic minorities finding a wellpaid job in the labour market, an investment in longer education can be perceived as less rewarding than for majority persons. For example Zang (2008) reports from a survey for 2001 for Lanzhou the capital of Gansu, that Hui ethnicity is a barrier for being employed in state firms, alternatively another state unit, compared to Han ethnicity.

At the household level, education is typically transmitted from one generation to the next due to resource constraints as well as preferences. This is a worldwide phenomenon (Herz et al 2007) also present in China (Knight et al, 2013). A shorter length of education for minority children can be traced to shorter educations of their parents and ethnic disparities in length of education can thus be transmitted from one generation to the next.

It is a great challenge for research to discern the importance of various possible reasons for ethnic dispersions on length of schooling. In this paper we investigate three possible and interrelated mechanisms: The association between length of schooling and income (Section 
7), priorities of parents (Section 8) as well as importance of the intergenerational transmission in length of education (Section 9).

\section{Hui and Ningxia}

The People's Republic of China officially defines ethnic minority individuals as those belonging to one of 55 different recognised ethnic minorities and not the Han majority. Ethnic status is registered on the identification card each citizen of China possesses. In PRC policy, minorities are given certain advantages. For example, many minorities can benefit from preferred treatment regarding entry to higher education, and many minority groups are exempted from the one-child policy. A positive assessment of ethnic diversity appears to be widely embraced by the Chinese population in theory if not in practice. ${ }^{3}$ Ethnic tensions still exist.

China recognises ten Muslim minorities: Hui, Uyghur, Kazak, Dongxiang, Uzbek, Bonan, Tartar, Tajik, Salar and Kirgiz. Hui is the third largest ethnic minority group in the People's Republic of China after Zhuang and Manchu. According to the national Census 2010, the Hui number 10586 078, or 0.79 per cent of the population of the People's Republic of China. Hui are of varied ancestry. Some are descendants of foreign Muslims who long ago moved into China as traders from Central Asia and Persia and mixed with the Han. ${ }^{4}$ Hui are similar to the Han majority in many aspects of culture including language. However, many take part in

\footnotetext{
${ }^{3}$ According to World Value Study 2005 not less than 90 percent of Chinese respondents agreed more with the statement "Ethnic diversity enriches life" than the statement "Ethic diversity erodes a country's unity", see http://www.wvsevsdb.com/wvs/WVSDocumentation.jsp?Idioma=I

${ }^{4}$ For the history of Hui see for example Chang (1987), Lipman (1997) or Chuah (2004).
} 
religious activities and as Muslims they follow Islamic dietary laws. Their mode of dress also differs to some extent; women often wear headscarves and men white caps. Certain family names also signal that the person most probably belongs to the Hui minority. Hui typically marry within their ethnic group (see Zang, 2007).

Hui are also characterised by low school enrolment rates, particularly among girls. ${ }^{5}$ Some scholars attribute this to the persistency of patriarchal values on female roles, early marriage as well as limitations imposed not only by parents but the group itself (see Bai et al, 2006 and Sun, 2009). Other possible reasons are the relatively low quality of the schools Hui are enrolled in, that attendance at a religious school can function as a partial substitute for formal schooling and also that the payoff from formal education is lower for Hui than for Han.

In contrast to other ethnic minorities, the Hui are spread all over China's 31 province level units with the highest concentration in Ningxia. A visitor to Ningxia is struck by the large number of mosques visible, particularly in rural areas. Among the People's Republic of China, 31 province level units five have been given the status of autonomous region; Tibet, Xinjiang, Inner Mongolia, Guangxi and Ningxia. Ethnic regional autonomy is mainly cultural (for example in allowing official use of the language), and social (in building a cadre force and middle class). Ningxia Hui autonomous region (Níngxià Huízú Zìzhìqū) was formed in 1958. It is bounded by Shaanxi in the east, Gansu in the south and west, and Inner Mongolia Autonomous Region to the north. This mostly sparsely settled, mostly desert region lies partly on the Loess Plateau and in the vast plain of the Yellow River. Natural conditions are unfavourable for agriculture activities in many parts of Ningxia, and the government has

\footnotetext{
${ }^{5}$ See Hannum (2001) who reports enrolment rates among children aged 7 to 12 in 1992 for 17 minority groups. Tibetan and Hui are found to have the lowest enrolment rates.
} 
initiated resettlement projects (see Merkle, 2003) and land conversion programmes (see Zhang et al, 2008 and Demurger and Wan, 2012) for some decades now.

Of Ningxia's population of 6.25 million persons in 2009, one-third are Hui and two-thirds are Han. Almost half (46 percent in 2009) of Ningxia's population live in cities, a proportion almost identical to China as a whole. The existence of the Hukou system long limited rural to urban mobility as in other parts of China, thereby contributing to keeping the urban to rural income gap high (Sicular et al 2007, Whyte, 2010). In the data we present in Section 4, the gap in per capita household income between urban and rural areas is 2.60 to 1 . As we document in Section 5, the urban to rural gap in length of schooling is among adults substantial in Ningxia and in many cases females have shorter educations than males.

\section{Data and some basic facts}

The research presented in this paper uses data from a socioeconomic survey conducted in 2007 in the Ningxia Hui Autonomous Region by the Ningxia Survey Team of the National Bureau of Statistics for the Institute of Ethnology and Anthropology, Chinese Academy of Social Sciences. Ningxia Hui Autonomous region consists of five cities at prefecture level (the capital Yinchuan, Sizuishan, Wuzhong, Guyan and Zhongwei) divided into 22 county level units. ${ }^{6}$ The samples were selected from the larger pool of households surveyed in the region used for official statistical information published each year in the statistical yearbook for Ningxia Autonomous region. This was done by taking all regularly sampled households in

\footnotetext{
${ }^{6}$ The number of county level units in each city are: Yinchuan: 6, Shuizuishan and Zhongwei: each 3, Wuzhong and Guyuan each 5. Data on education expenditures and total expenditures refer to the preceding year, 2006.
} 
rural areas and a random sample of 800 households in urban areas regularly surveyed. Among five cities at the prefecture level in Ningxia three cities (Wuzhong, Guyan and Zhongwei) were surveyed in the southern part of Ningxia where Hui make up a large proportion of the population. ${ }^{7}$ For the households surveyed we received access to information already collected by the survey team. The research team also designed questionnaires for the rural and urban households, respectively. The response rate was very high (100 percent in the urban survey, 99.72 percent in the rural survey).

The rural survey contains 1190 households with 5399 individuals and covers 120 villages. In the sample 3028 persons (57 percent) belong to the majority and 2289 persons (43 percent) to the Hui ethnic minority. The urban survey contains 800 households with 2455 persons. Of those 1680 persons (69 percent) are majority, and 715 persons (29 percent) are Hui. There are also 43 persons (2 percent) belonging to other minorities (mostly Manchu) which we do not use in the analyses presented here.

/Table 1 about here/

Table 1 provides some basic information on the two ethnic groups in rural as well as urban Ningxia obtained from the survey. The Hui population has a larger proportion of children than the Han and consistently Hui households have a somewhat larger number of members than Han households. Households are smaller in size in urban Ningxia than in rural Ningxia. Many urban residents have migrated from rural areas as Table 1 shows that in each ethnicity about half are rural-born. Marriages across ethnic groups are very uncommon in rural as well as

\footnotetext{
${ }^{7}$ The total number of Hui persons in the sample is 2257 of which 1732 are from the southern part of Ningxia (Wuzhong, Guyuan and Zhongwei) representing 76.7 percent of all Hui in the sample.
} 
urban Ningxia. The largest proportion inter-married is among urban Hui females where not more than 5 percent have married outside their ethnicity. While almost all Hui respondents indicate that they are religious, this was only the case among a minority of Han respondents. Urban inhabitants are much more likely to be members of China's Communist Party than rural people, but within each region there is no ethnic difference in the frequency of party membership.

\section{Years of schooling among adults}

Results on years of schooling by gender in rural as well as urban Ningxia for Hui and Han are reported in Table 2. The table also provides information on educational attainment. ${ }^{8} \mathrm{We}$ report gaps along all three dimensions: urban inhabitants have longer educations than rural inhabitants, males have longer educations than females and Han have longer educations than Hui. Largest is the urban - rural gap. For example, male Han living in rural Ningxia have 7 years of schooling compared to 11 years among urban male Han, a difference of not less than 4 years. The ethnic gap and the gender gap in years of schooling are approximately of equal size. For example, male Hui living in rural Ningxia have 1.4 fewer years of education than rural male Han, but also 2 years more of education than Hui females. Considering all three dimensions together shows fairly large differences in years of schooling; adult rural Hui females have on average only 3.5 years of schooling, and adult urban males of both ethnicities have on average 11 years. Examining length of education more in detail we find that in contrast to what is the case in urban Ningxia, rather few adults in rural Ningxia have an

\footnotetext{
${ }^{8}$ The Census 2000 also reports education by gender in rural as well as urban Ningxia. Our estimates show generally higher proportions of people with longer educations, which most probably is because they refer to 2007; an expansion of education took place between 2000 and 2007.
} 
education of college or above. Illiteracy is found in both ethnic groups in rural Ningxia and among females in urban Ningxia, but is very low among urban males of each ethnicity. Of note is that among rural Hui females as many as 45 percent are classified as illiterate. ${ }^{9}$

/Table 2 about here/

We have thus established that adult Hui have shorter educations on average than their Han counterparts. However, have the ethnic gaps narrowed over time during the period that China experienced a rapid expansion of education? We can study this by dividing the samples by birth cohorts, and do so for rural as well as urban adults. ${ }^{10}$ We define four age-cohorts in such a way that differences between them mirror époques in Chinese social and educational history (see for example Hannum, 1999 or Lu and Treiman, 2008).

The oldest cohort (aged 64 and older at the time of the survey) completed education during the pre-Communist era (before 1950) when China's economy suffered from approximately two decades of war and many serious economic problems. Educational opportunities were extremely unfavourable and the educational system was badly disrupted. The second cohort (aged 49 to 63 at the time of the survey) received education during the early years after the foundation of the People's Republic. During the initial phase of this period the economy

\footnotetext{
${ }^{9}$ Census data for Ningxia 1990 cited by Bhalla and Qiu (2006) shows that as many as 65 percent of female minority persons in Ningxia were illiterate at that time. Only Tibet, Gansu and Qinghai had higher illiteracy rates for female minorities.

${ }^{10}$ Please note that we classify persons according to where they live at the time of the survey. Some of the people who are questioned in the urban survey grew up in rural Ningxia. This means that not only urban circumstances have generated the educational disparities (or lack of disparities) in urban Ningxia. Furthermore, the education gaps we report for rural Ningxia do not consider the population which has left the region for urban areas or for locations outside Ningxia.
} 
recovered and the education system expanded. Educational policies emphasized economic development and social equity. However, the Great Leap Forward during 1958 to 1960 led to serious economic collapse and a nationwide Great Famine and many families kept their children out of school.

The third cohort (aged 37 to 48 at the time of the survey) was educated during the Cultural Revolution. Policies during this period promoted educational equality by different means. The number of schools in rural areas expanded while higher institutions of learning (located in cities) were initially closed. The policy explicitly aimed to reduce class- and gender-based differences in educational attainment. The fourth birth cohort was educated in reform China. After 1978, education financing was changed from a centralized to a decentralized system, and as a consequence spatial differences can be supposed to have become more important. In addition, schooling fees increased, which can be assumed to have particularly affected children in poor areas. Several factors thus worked towards increased dispersions in length of schooling. However, working in the opposite direction, household income increased and number of children born in an average household decreased, making it possible for more and more parents to afford to have their child/children educated for longer periods.

One would expect that taken separately, the more egalitarian values guiding policy during the second and third époques would have reduced disparities due to gender and ethnicity, while this is not necessarily the case for the most recent period. What does our data show? We report the answer in a sequence of figures based on a table documented in the Appendix.

/Figure 1 and Figure 2 about here/ 
Starting with rural Ningxia, Figure 1 clearly shows that the gender gap in length of schooling was reduced in relative terms, but not in absolute terms, across birth cohorts. Note that the gender gap actually is smallest in the generation educated in reform China, but also that full gender equality has not been reached in this cohort. In contrast, when it comes to the ethnic gap we cannot report a clear tendency of Hui catching up to Han in terms of years of education, see Figure 2. ${ }^{11}$ The same figure also shows that among people belonging to a birth cohort, the ethnic education gap is larger among females than among males.

/Figure 3 and Figure 4 about here/

Figure 3 shows rather large differences in years of schooling by gender as well as ethnicity in the oldest cohort for urban residents. However, the increase among female Han was rapid, causing the third cohort to catch up with their male counterparts, a position that continues in the youngest cohort. As Figure 4 also shows, Hui males in the third cohort caught up with their Han counterparts, which was maintained in the youngest cohort. Hui females have also improved their situation compared to Han males belonging to the same cohort. However, in the youngest cohort, urban Hui females still have somewhat shorter educations than the other three categories.

\section{Education among parents and teenagers}

\footnotetext{
${ }^{11}$ In Figure 2 and Figure 4 we do not show education among persons aged 64 and older due to a relatively low number of observations in the survey.
} 
/Table 3 about here/

The preceding section has shown that adults from later-born cohorts in Ningxia have longer educations than those born earlier. The educational expansion can also be inspected by analysing how long parents of adults were educated. This is possible as the survey also included questions on length of education among parents of adult household members. The questions were phrased so that the answers were not dependent on whether the parent was living with the respondent, nor that the parent was alive at the time of the survey. Table 3 shows that as expected, parents had considerably shorter educations than the adults surveyed. For example, among rural male Han, average years of education had increased from 3.2 years among the parents to 7.0 years among the surveyed individuals - almost a doubling over a generation. There is also an increase to about double length of schooling among most other categories, and among urban Hui males the increase is even somewhat larger. Without exception, Hui parents had shorter educations than their adult children.

\section{/Table 4/}

The ethnic differences in rural Ningxia among adults reported in the preceding section appear to continue in the generation now growing up. School attendance rates among children aged 10 to 17 in rural Ningxia at the time of the survey are substantially lower for Hui than for Han. Table 4 shows little variation in school attendance rate by gender, but by ethnicity. Almost all urban teenagers attended school in 2006 irrespective of gender and ethnicity. 
However, one out of ten rural Han were not in school, as was true for one out of four rural Hui. $^{12}$

\section{The association between length of education and income among Hui and Han}

In order to investigate if the association between length of education and income is weaker among Hui and Han we define two new samples. The first is made up of person aged at least 18 years who are rural born by adding all adults in the rural in the sample with people who are rural born in the urban sample. ${ }^{13}$ The other, and smaller, sample is made up of those adults in the urban sample who are urban born, For both samples we regress household disposable per capita income on age of the person and variables indicating the number of years of education interacted with ethnicity. The results reported in Table 5 show weaker association between length of education and per capita income among Hui in the sample of urban-born adults, ${ }^{14}$ However, while in the urban born sample the differences between ethnicities is statistically significant (F-test) at the 1 percent level in sample of rural-born adults is the difference marginal, and not statistically significant at conventional levels.

/Table 5 about here/

\section{Education expenditures among rural Han and Hui}

\footnotetext{
${ }^{12}$ Our data shows that most teenagers not in education were in employment. Using data from the China Household Income project (CHIP) 1988 and 1995 Bhalla and Qiu (2006) shows that for children aged 13 to 18 and living with parents, minority status had a negative effect on education attainment in rural China after controlling for other characteristics such as education of household head, spatial variables and household per capita income.

${ }^{13}$ This assumes that all person observed in the rural born are also rural born. This assumption is most probably true in almost all cases as migration to rural areas is very limited among persons who are born in an urban area with an urban hukou (residents permit).

${ }^{14}$ This is consistent with what Li and Ding (2013) report from earnings function analysis for urban residents (rural or urban born) using the same data.
} 
How should we interpret the fact that even the Hui teenage generation in rural Ningxia is disadvantaged in length of schooling compared to Han? One possible reason is that Hui put a lower value on education then Han

One way to investigate the latter is to inspect the expenditures households with different ethnicities allocate to education. Do Hui households allocate less to education than Han? If this is the case, does a relationship exist once we control for parental education? We can find information on educational expenditures in the rural questionnaire where the variable expenditures for the preceding year (2006) on all types of education (arranged by local government as well as by religious institutions) are available. Table 4 (see Section 6) shows that in households with children under age 14, rural Hui actually spend less money on education than rural Han parents. This is true when we compare absolute amounts of expenditures, but also when we relate education expenditures to total consumption.

/Table 6 about here/

Why are rural Hui households in Ningxia spending less on education than Han households? In order to understand this better, we analyse data for all rural households using regression models. The dependent variable is the amount of annual expenditures (in Yuan) a household had on education in 2006. In the first model we relate the household's expenditure on education to variables measuring the number of children of a specific age, one dummy indicating if the household has no child and a dummy indicating Hui ethnicity of the household. The model was estimated by Ordinary Least Squares. The results reported in the first column of Table 6 show that as expected, education expenditures vary clearly by age of the child and that Hui ethnicity shows a negative association. When adding length of parent 
education to the specification this variable is unsurprisingly found to have a positive coefficient. However, it is estimated with a low t-value. The table also shows that the coefficients for Hui ethnicity are similar in the two specifications. Thus the gap in educational expenditures between Han and Hui are due to other factors (for example culture) than the gap in parent's length of education.

\section{Intergenerational links in length of schooling}

We have found clear indications of persistent disadvantages for Hui compared to Han across birth cohorts and over generations when inspecting groups of people. Does an intergenerational link also appear at the individual level meaning that offspring of longerschooled parents in Ningxia have longer educations, and what role would this play for the persistent disadvantages in length of education between Hui and Han? One should understand that this kind of analysis aims to describe the strength of the intergenerational link in length of education, not to explain it. ${ }^{15}$

/ Table 7 about here/

\footnotetext{
15 There is now a growing literature attempting to establish a causal relationship between the education of parents and their children that uses one out of three strategies: by analysing identical twins, studying adoptees and using instrumental variables. In the last strategy, education reform has often been used as instrument for education. Holmlund et al (2011) summarises the literature and concludes for example, that for all studies surveyed, causal effects are smaller than cross-section estimates.
} 
We investigate the intergenerational links in years of schooling for adults in the urban sample. ${ }^{16}$ The dependent variable is the length of schooling. In Table 7 we first relate years of education to dummies defined as interactions between ethnicity, gender and age. "Male Han aged 35 at most" is the omitted category. The models are estimated by Ordinary Least Squares. We see again that among those belonging to the youngest age cohorts in urban Ningxia, there is no statistically significant difference in years of schooling between Han males on the one hand, and Han females as well as Hui males on the other. In contrast, coefficients for being Hui female and belonging to the two older cohorts are rather large. The gap in years of schooling between a young male Han and a Hui female over age 64 is as large as 9.8 years.

In the specification reported in the second column of Table 7 we have added mean year of schooling among parents as explanatory variable to the specification. We find a positive coefficient amounting to 0.23 and it is estimated with high t-statistics. We have thus found that for people living in urban Ningxia, year of schooling in the second generation is positively related to years of schooling in the first generation. However, a coefficient of 0.23 is not particularly large. It means that if we compare two individuals of the same age and gender, one having parents with five years of schooling and the other with ten years of schooling, the expected difference in own length of schooling is not more than 1.2 years. Including years of schooling for parents in the model makes the estimated coefficient for Hui ethnicity that has t-statistics over 2 decrease. However, the decreases are in all cases less than half of the value of the coefficients reported in the first column. We have thus found that although the fewer years of schooling of Hui parents contribute to explain why Hui persons

\footnotetext{
${ }^{16}$ Our samples are not ideal for studying the intergenerational link in length of education, as some rural-born people have migrated to the cities, and migration can be supposed to be influenced by length of education. Note that some of the people in the urban sample are not urban-born.
} 
have shorter educations than Han, it cannot explain most of the ethnic differences. Other factors must also contribute. For example, education decisions are typically influenced not only by parents, but also by peers and role models often belonging to the same ethnic group.

In the specification reported in the third column we allow the coefficient for parental education to vary across birth cohorts and find an interpretable pattern. Most importantly, the intergenerational relation was strongest in the pre-PRC époque, and lowest but still existing in the generation educated during the Cultural Revolution. This coefficient is only about onethird of the corresponding coefficient for persons educated in pre-PRC China. The period of the Cultural Revolution was thus a period when the link in length of schooling was the weakest. However, it was still positive. ${ }^{17}$

\section{Conclusions}

In this study we have investigated length of schooling among people belonging to the Hui ethnic group (a Muslim minority), and the Han majority living in Ningxia-Hui autonomous region of China. The analysis is based on surveys collected in 2007 for rural as well as urban areas We have reported substantial ethnic gaps in years of schooling disfavouring Hui adults in rural Ningxia and the older cohorts in urban Ningxia. That Hui on average have shorter educations than the ethnic majority is a phenomenon that has lasted over generations. Years of schooling in the population of Ningxia also differs between rural and urban areas, by gender and not least by when the person was born.

\footnotetext{
${ }^{17}$ In Table A1 in the Appendix we report Gini coefficients for length of schooling in the four rural and urban birth cohorts. The Gini coefficient is an inequality index often used when analysing the distribution of income. It takes values from 0 , standing for complete equality, to 1 representing maximum inequality. The table shows that inequality in years of schooling reduced across cohorts, with the exception of that between the two youngest cohorts in urban Ningxia. The table also shows that inequality in years of education is smaller in urban Ningxia than in rural Ningxia.
} 
China has seen a long period of education expansion which made us hypothesise that ethnic differences in length of education have diminished. Analyses of four birth-cohorts of adults show several equalisations in years of schooling over time. Gender gaps have narrowed and in some cases also ethnic gaps. The latter has been the case in urban Ningxia, However, in rural Ningxia there is actually very little evidence of narrowing ethnic disparities in years of schooling across the birth cohorts of adults.

Why do Hui persons have shorter educations than Han individuals? Our regression analysis shows that among urban-born adults (but not among rural-born adults) is the association between years of schooling and length of schooling weaker among Hui than among Han. Thus Hui have lower incentives than Han to invest in length of schooling, We also reported that rural Hui households on average spend fewer resources on education than rural Han households. An analysis of the intergenerational link in length of education for urban Ningxia showed that length of schooling in one generation is transmitted to the next. We also found that this link became weaker for children attending school after the People's Republic was established. However, this mechanism cannot explain most of the ethnic differences in length of schooling.

From the policy perspective that closing ethnic and gender gaps in years of schooling is desirable, we have reported good as well as bad news. Good news is that ethnic disparities, as well as gender differences in years of schooling, have diminished in urban Ningxia across birth cohorts. In contrast not much of progress has been made in reducing ethnic differences in length of schooling in rural Ningxia. This is in contrast with the achieved decreases in 
gender disparities. It should also be remembered that in rural Ningxia in 2007, almost one in two adult Hui females are illiterate.

We round off by asking: To what extent can our findings for Hui be generalised to China's other Muslim minority groups? The answer, based on computations made for persons aged 25 and older from the 2005 sample census for the larger groups, is that there is a perhaps surprisingly large dispersion in years of schooling across China's ethnic minorities living in rural areas. The education gap in length of schooling between on the one hand, Kazakhs, Uighur and Kyrgyz, and on the other hand Han, is smaller than the gap between Hui and Han. In contrast, rural Salar and rural Dongxian show remarkably short lengths of schooling. ${ }^{18}$ In urban China such disparities towards the ethnic majority is considerably smaller.

\footnotetext{
${ }^{18}$ The numbers of years of education among adult persons was for rural China: Kazakhs 7.2, Han 6.6, Uighur 6.1, Kyrgyz, 6.0, Hui 4.5, Salar 2.5 and Dongxian 1.5. Estimates for urban China are 11.1 years for Kazak, 10.5 years for Uighur, 10.4 for Han and 9.9 for Hui. There are too few observations among other minorities in the 2005 sample survey to make estimates meaningful. We thank Xiuna Yang for having made the computations.
} 


\section{References}

Bai, G., Yan, X. and Li, X. (2006) "Multiple Difficulties and Countermeasures on the Development of the Hui Nationalities' Education in Ningxia", Value Engineering, No.10, (In Chinese).

Bhalla, A.S. and Qiu, S. (2006) Poverty and Inequality among Chinese Minorities, London and New York: Routledge.

Chang, H.Y (1987) “The Hui (Muslim) Minority in China: An Historical Overview”, Journal of Muslim Minority Affairs, 8, 62- 78.

Chuah, O. (2004) "Muslims in China: The Social and Economic Situation of Hui", Journal of Muslim Minority Affairs, 24, 155-162.

Demurger, S. and Wan, H. (2012) "Payments for Ecological Restoration and Internal Migration in China: The Sloping Land Conversion Program in Ningxia", IZA Journal of Migration, 1:10.

Hannum, E. (1999) "Political Change and the Urban-Rural Gap in Basic Education in China, 1949-1990”, Comparative Education Review, 43, 193-211.

Hannum, E. (2002) "Educational Stratification by Ethnicity in China: Enrolment and Attainment in the Early Years" Demography, 39, 95-117. 
Hannum, E., Behrman, J. Wang, M and Liu, J. (2008) "Education in the Reform Era" in Brandt, L. and Rawski, T. (Eds) China's Great Economic Transformation, Cambridge: Cambridge University Press.

Hannum, E. and Wang, M. (2012) “China. A Case Study in Rapid Poverty Reduction” in Hall, G. and Patrinos, H. (Eds) Indigenous Peoples, Poverty and Development. Cambridge: Cambridge University Press.

Hertz, T. Jayasundera, T., Pirano, P., Selcuk, S., Smith, N. and Verashchagina, A. (2007) "The Inheritance of Educational Inequality: Intergenerational Comparisons and Fifty-year Trends”, B.E. Journal of Economic Analysis \& Policy, 7, Issue 2, Article 10.

Holmlund, H., Lindahl, M. and Plug. E. (2011) “The Causal Effect of Parents' Schooling on Children's Schooling” Journal of Economic Literature, 49, 615-51.

Knight, J., Sicular, T. and Yue, X. (2013) "Educational Inequality in China: The Intergenerational Dimension”, In Li, S, Sato, H. and Sicular, T. (eds) Rising Inequality in China. Challenges to a Harmonious Society, Cambridge: Cambridge University Press.

Li S. and Wang Y. (2003) "The Choice Made When Faced with the Dilemma in Hui Nationalities' Education at Present”, Researches on the Hui, No.2. (In Chinese)

Li S. and Ding, S. (2013) “An Empirical Analysis of Income Inequality between a Minority and the Majority in Urban China: The Case of Ningxia Hui Autonomous Region", $\underline{\text { Review of }}$ Black Political Economy, 40, 341-355. 
Lipman. J. (1997) Familiar Strangers. A History of Muslims in Northwest China, University of Washington Press.

Lu, Y. and Treiman, D. (2008) "The Effect of Sibship Size on Educational Attainment in China: Period Variations", American Sociological Review, 73, 813-834.

Ma, X. (2006) “On Social Changes and Development of Religious Education in Linxia Ningxia Hui Autonomous Region”, Journal of the Second North West University for Nationalities, No.4. (In Chinese)

Merkle, R. (2003) "Ningxia's Third Road to Rural Development: Resettlement Schemes as a Last Means to Poverty Reduction?”, Journal of Peasant Studies, 30, 160-191.

Matsumoto, M. and Shimbo, A. (2011) "Islamic Education in China. Triple discrimination and the challenge of Hui women's madrasas" pages 85 - 102 in Sakurai, K and Adelkhak, F (editors) The Moral Economy of the Madrasa. Islam and Education Today, Oxton: Routledge.

Ningxia Daily (2012) “Ningxia University Examination Policy in 2012”, May 6, http://www.nxnet.cn/olddate/nxrb/2012-05/16/

Postiglione, G. (2009) “The Education of Ethnic Minority Groups in China”, in Banks, J. Editor, The Routledge International Companion to Multicultural Education, New York and London: Routledge. 
Sicular, T. , Yue, X., Gustafsson, B. and Li, S. (2007) “The Urban - Rural Income Gap and Inequality in China", Review of Income and Wealth, 53, 93-126.

Sun B. (2009) "Returns to Education of Different Nationalities: A Comparison of the Han, Tibetan and Hui Nationalities", Journal of Research on Education for Ethnic Minorities, No.5, Vol.20 General No.94. (In Chinese)

Teng, W. and Ma, X. (2009) "Preferential Policies for Ethnic Minorities and Educational Equality in Higher Education in China", in Zhou, M. and Maxwell Hill, A. (Eds) Affirmative Action in China and the U.S.: A Dialogue on Inequality and Minority Education, New York: Pelgrave Macmillan.

United Nations Development Program (2005) Development with Equity, China Human Development Report 2005, China Translation \& Publishing Company.

Wang, T. (2007) "Preferential Policies for Ethnic Minority Students in China's College/University Admission", Asian Ethnicity, 8, 149-163.

Zhang, L., Tu, Q., Mol, P.J. (2008) "Paying for Environmental Services: The Sloping Land Conversion Program in Ningxia Autonomous Region of China", China \& World Economy, $16,66-82$. 
Zhang, X. (2007) Ethnicity and Urban Life in China. A comparative study of Hui Muslims and Han Chinese, London and New York: Routledge.

Zang, X. (2008) "Market Reform and Han-Muslim Variation in Employment in the Chinese State Sector in a Chinese City", World Development, 36, 2341-2352.

Whyte, M. K. (Ed) One Country, Two Societies. Rural-Urban Inequality in Contemporary China, Cambridge Mass: Harvard University Press. 
Table 1

Descriptive statistics on Han and Hui persons in urban and rural Ningxia

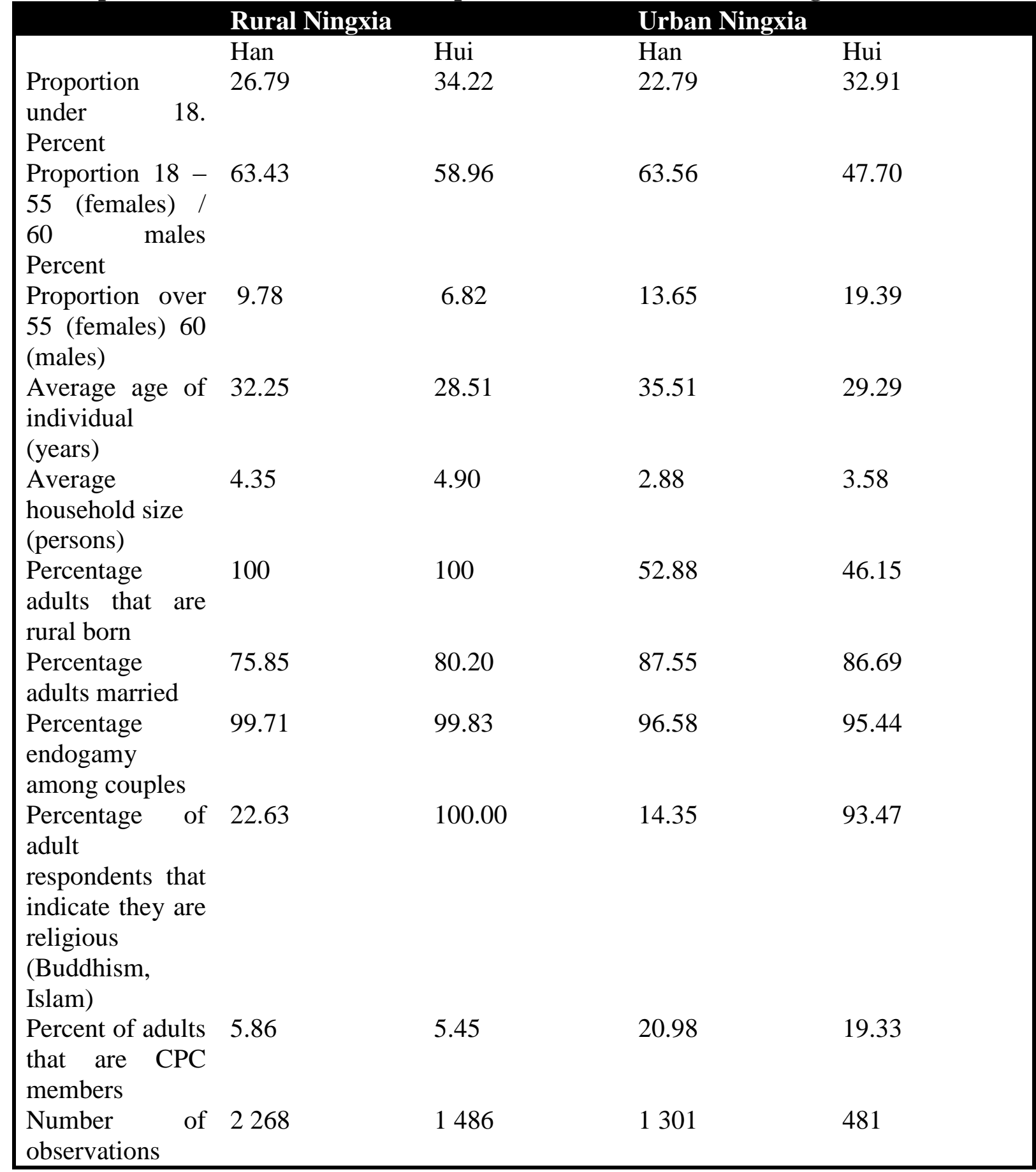

Source: Ningxia Household Income Survey

Note: There is a large non-response in the question on ethnicity among three best friends as answers were obtained by 555 / 556 Han / Hui respondents in rural areas and by 1509/625 Han/Hui in urban areas. The question of endogamy was answered by 1715 / $1176 \mathrm{Han} / \mathrm{Hui}$ in the rural sample and 1139 / $417 \mathrm{Han} / \mathrm{Hui}$ in the urban sample The question on religion was answered by $2721 / 2050$ Han/Hui in the rural sample and 1531 / 680 $\mathrm{Han} / \mathrm{Hui}$ in the urban sample. 
Table 2

Years of schooling among adult Han and Hui in rural and urban Ningxia

\begin{tabular}{|c|c|c|c|c|c|c|c|c|}
\hline & Rural & ingxia & & & Urban & Tingxia & & \\
\hline & Han & & Hui & & Han & & Hui & \\
\hline & Males & Females & Males & Females & Males & Females & Males & Females \\
\hline & & & ercen & $\mathrm{age}$ & & & & \\
\hline $\begin{array}{l}\text { University } \\
\text { and above }\end{array}$ & 1.77 & 1.67 & 1.17 & 0.85 & 12.32 & 6.21 & 12.23 & 9.02 \\
\hline College & 1.27 & 1.30 & 1.56 & 0.71 & 19.19 & 17.12 & 23.21 & 15.16 \\
\hline $\begin{array}{l}\text { Senior } \\
\text { middle } \\
\text { school }\end{array}$ & 16.80 & 9.80 & 11.12 & 4.64 & 36.20 & 33.19 & 25.74 & 20.09 \\
\hline $\begin{array}{l}\text { Junior } \\
\text { middle } \\
\text { school }\end{array}$ & 45.35 & 34.04 & 34.15 & 19.30 & 25.74 & 27.88 & 27.43 & 23.36 \\
\hline $\begin{array}{l}\text { Primary } \\
\text { school }\end{array}$ & 23.56 & 25.42 & 33.51 & 29.58 & 4.99 & 8.03 & 10.55 & 13.93 \\
\hline Illiterate & 11.23 & 28.77 & 18.37 & 44.79 & 1.56 & 7.58 & 0.84 & 18.44 \\
\hline $\begin{array}{l}\text { Years of } \\
\text { schooling } \\
\text { Number of } \\
\text { observations }\end{array}$ & 6.99 & 5.28 & 5.58 & 3.51 & 11.08 & 9.93 & 11.12 & 8.50 \\
\hline Adults & 1185 & 1083 & 774 & 712 & 637 & 659 & 244 & 246 \\
\hline
\end{tabular}

Source: Ningxia Household Income Survey

Table 3

Years of schooling and education attainment among adults and parents in rural and urban Ningxia

\begin{tabular}{|c|c|c|c|c|c|c|c|c|}
\hline & \multicolumn{4}{|c|}{ Rural Ningxia } & \multicolumn{4}{|c|}{ Urban Ningxia } \\
\hline & Han & & Hui & & Han & & Hui & \\
\hline & Males & Females & Males & Females & Males & Females & Males & Females \\
\hline \multicolumn{9}{|c|}{ Percentage } \\
\hline $\begin{array}{l}\text { Adults years } \\
\text { of schooling }\end{array}$ & 6.99 & 5.28 & 5.58 & 3.51 & 11.08 & 9.93 & 11.12 & 8.50 \\
\hline $\begin{array}{l}\text { Parent's } \\
\text { years of } \\
\text { schooling } \\
\text { Number of } \\
\text { observations }\end{array}$ & 3.23 & 2.98 & 2.16 & 1.89 & 4.50 & 4.89 & 3.83 & 3.54 \\
\hline Adults & 1185 & 1083 & 774 & 712 & 637 & 659 & 244 & 246 \\
\hline $\begin{array}{l}\text { Parents of } \\
\text { adult }\end{array}$ & 804 & 559 & 528 & 364 & 620 & 626 & 232 & 244 \\
\hline
\end{tabular}

Source: Ningxia Household Income Survey 


\section{Table 4}

School attendance rates among teenagers and education expenditures among rural and urban households in rural and urban Ningxia

\begin{tabular}{|c|c|c|c|c|c|c|c|c|}
\hline & \multicolumn{4}{|c|}{ Rural Ningxia } & \multicolumn{4}{|c|}{ Urban Ningxia } \\
\hline & $\begin{array}{l}\text { Han } \\
\text { Males }\end{array}$ & Females & $\begin{array}{l}\text { Hui } \\
\text { Males }\end{array}$ & Females & $\begin{array}{l}\text { Han } \\
\text { Males }\end{array}$ & Females & $\begin{array}{l}\text { Hui } \\
\text { Males }\end{array}$ & Females \\
\hline & & & ercen & $\mathrm{age}$ & & & & \\
\hline $\begin{array}{l}\text { Percentage } \\
\text { of teenagers } \\
\text { (persons } \\
\text { aged } 10 \text { to } \\
\text { 17) in school }\end{array}$ & 89.34 & 92.47 & 76.92 & 73.45 & 100.00 & 100.00 & 100.00 & 98.21 \\
\hline $\begin{array}{l}\text { Household } \\
\text { educational } \\
\text { expenditures, } \\
\text { households } \\
\text { with children } \\
\text { (person less } \\
\text { than } 14 \\
\text { years), } \\
\text { RMB }\end{array}$ & 930.73 & & 555.18 & & N A & & $\mathrm{NA}$ & \\
\hline $\begin{array}{l}\text { As percent } \\
\text { of total } \\
\text { consumption } \\
\text { Number of } \\
\text { observations }\end{array}$ & 4.69 & & 3.22 & & N A & & $\mathrm{NA}$ & \\
\hline Teenagers & 272 & 239 & 225 & 231 & 103 & 117 & 84 & 56 \\
\hline $\begin{array}{l}\text { Households } \\
\text { with children }\end{array}$ & 716 & & 417 & & 584 & & 203 & \\
\hline
\end{tabular}

Source: Ningxia Household Income Survey 


\section{Table 5}

The association between on one hand years of education among Han and Hui and per capita household income

a. Sample of rural-born adults aged at least 18 years

\begin{tabular}{|lll|}
\hline & Coefficient & T-value \\
Age & $\mathbf{7 2 . 9 6} * * *$ & $\mathbf{1 5 . 5 5}$ \\
Education year*Han & $\mathbf{4 0 5 . 3 3} * * *$ & $\mathbf{2 4 . 8 4}$ \\
Education year*Hui & $\mathbf{3 9 5 . 3 6} * * *$ & $\mathbf{1 7 . 8 6}$ \\
Constant & $\mathbf{- 1 0 5 0 . 0 9 * * *}$ & $\mathbf{- 4 . 1 0}$ \\
Adj R-squared & $\mathbf{0 . 1 3}$ & \\
Number of observations & $\mathbf{4 6 8 6}$ & \\
\hline
\end{tabular}

b. Sample of urban-born people aged at least 18 years

\begin{tabular}{|lll|}
\hline & Coefficient & \\
Age & $\mathbf{1 0 0 . 8 8 * * *}$ & T-value \\
Education year*Han & $\mathbf{4 8 8 . 0 5}_{* * *}$ & $\mathbf{7 . 4 0}$ \\
Education year*Hui & $\mathbf{3 9 5 . 4 1} * * *$ & $\mathbf{1 0 . 3 9}$ \\
Constant & $\mathbf{1 3 5 . 2 3}$ & $\mathbf{7 . 7 1}$ \\
Adj R-squared & $\mathbf{0 . 1 3}$ & $\mathbf{0 . 1 6}$ \\
Number of observations & $\mathbf{8 9 0}$ & \\
\hline
\end{tabular}

Source: Authors' estimate based on Ningxia Household Income Survey 
Table 6

Education expenditure functions rural Ningxia

\begin{tabular}{|lllll|} 
& Coefficient & T-value & Coefficient & T-value \\
\hline Number of persons aged under 6 & $-231.28 * *$ & -2.27 & $-230.27 * * *$ & -2.26 \\
Number of persons aged 13-15 & 78.88 & 0.83 & 76.77 & 0.81 \\
Number of persons aged 16-18 & $549.86 * * *$ & 5.97 & $552.63 * * *$ & 6.00 \\
Number persons aged over 18 and being students & $1365.05 * * *$ & 9.49 & $1362.74 * * *$ & 9.47 \\
No children family dummy & -48.06 & -0.29 & -37.50 & -0.22 \\
Hui household dummy & $-336.72 * * *$ & -3.17 & $-332.82 * * *$ & -3.13 \\
Parental education year & & & 6.72 & 1.04 \\
Constant & $638.90 * * *$ & 5.62 & $608.78 * * *$ & 5.19 \\
Adj R-squared & 0.15 & & 0.14 & \\
Number of observations & 1133 & & 1133 & \\
\hline
\end{tabular}

Source: Authors' estimate based on Ningxia Household Income Survey Note: This regression is based on household data. The definition of children is those aged 14 and under. The omitted age category is for those aged 7 to 12 (primary school students)

\section{Table 7}

\section{Length of education functions urban Ningxia}

\begin{tabular}{|c|c|c|c|c|c|c|}
\hline & Coefficient & $\begin{array}{l}\text { T- } \\
\text { value }\end{array}$ & Coefficient & $\begin{array}{l}\text { T- } \\
\text { value }\end{array}$ & Coefficient & $\begin{array}{l}\text { T- } \\
\text { value }\end{array}$ \\
\hline Male* Hui*64 and over & -5.42 & -5.35 & -4.33 & -4.35 & -4.53 & -4.47 \\
\hline Male*Han*64 and over & -2.97 & -5.89 & -2.00 & -4.00 & -2.33 & -4.21 \\
\hline Female*Hui*64 and over & -9.77 & -9.30 & -8.62 & -8.36 & -8.77 & -8.39 \\
\hline Female*Han*64 and over & -7.11 & -13.04 & -6.17 & -11.42 & -6.53 & -11.01 \\
\hline Male* Hui *48-63 & -2.60 & -3.94 & -1.74 & -2.67 & -1.66 & -2.43 \\
\hline Male $* \operatorname{Han} * 48-63$ & -1.82 & -4.53 & -1.11 & -2.77 & -1.04 & -2.22 \\
\hline Female*Hui*48-63 & -7.36 & -11.28 & -6.29 & -9.73 & -6.20 & -9.25 \\
\hline Female *Han*48-63 & -4.05 & -10.25 & -3.36 & -8.57 & -3.29 & -7.11 \\
\hline Male*Hui*37-47 & -0.12 & -0.25 & 0.66 & 1.42 & 0.96 & 1.88 \\
\hline Male*Han*37-47 & -0.36 & -1.04 & 0.05 & 0.15 & 0.46 & 1.09 \\
\hline Female*Hui*37-47 & -2.76 & -5.46 & -2.05 & -4.11 & -1.73 & -3.20 \\
\hline Female*Han*37-47 & -1.08 & -3.10 & -0.75 & -2.21 & -0.32 & -0.75 \\
\hline Male * Hui* -36 & 0.02 & 0.04 & 0.19 & 0.45 & 0.20 & 0.47 \\
\hline Female* Hui*' -36 & -1.79 & -4.34 & -1.38 & -3.42 & -1.35 & -3.35 \\
\hline Female* Han * -36 & -0.15 & -0.43 & -0.15 & -0.45 & -0.15 & -0.46 \\
\hline Mean years of schooling of parents & & & 0.23 & 9.70 & & \\
\hline $\begin{array}{l}64 \text { and over } * \text { Mean years of } \\
\text { schooling parents }\end{array}$ & & & & & 0.46 & 4.91 \\
\hline $\begin{array}{l}48-63 * \text { mean years of schooling } \\
\text { parents }\end{array}$ & & & & & 0.24 & 4.40 \\
\hline $37-47 *$ mean years of schooling & & & & & 0.1569 & 3.99 \\
\hline $\begin{array}{l}\text { - } 36 * \text { mean years of schooling } \\
\text { parents }\end{array}$ & & & & & 0.2440 & 7.03 \\
\hline Constant & 11.85 & 48.67 & 10.46 & 37.67 & 10.35 & 33.31 \\
\hline Adj R-squared & 0.22 & & 0.26 & & 0.26 & \\
\hline Number of observations & 1781 & & 1781 & & 1781 & \\
\hline
\end{tabular}

Source: Authors' estimate based on Ningxia Household Income Survey 
Figure 1

Average years of schooling in rural Ningxia 2006 by birth cohort, gender and ethnicity

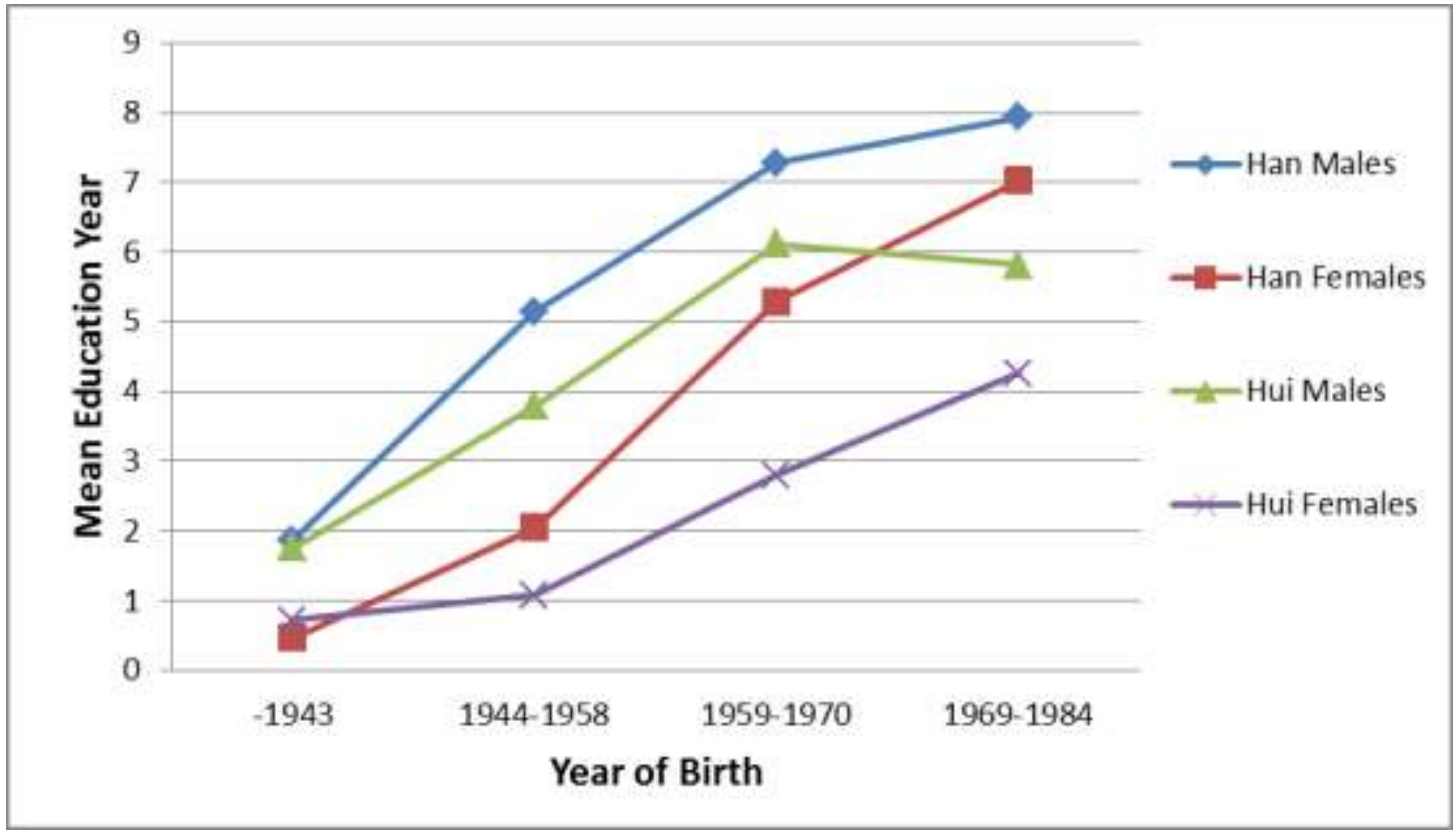

Source: Table A1. 
Figure 2

Ethnicity gaps in years of schooling in rural Ningxia by birth cohort

Average years of schooling among Hui as percent of average length of schooling among Han

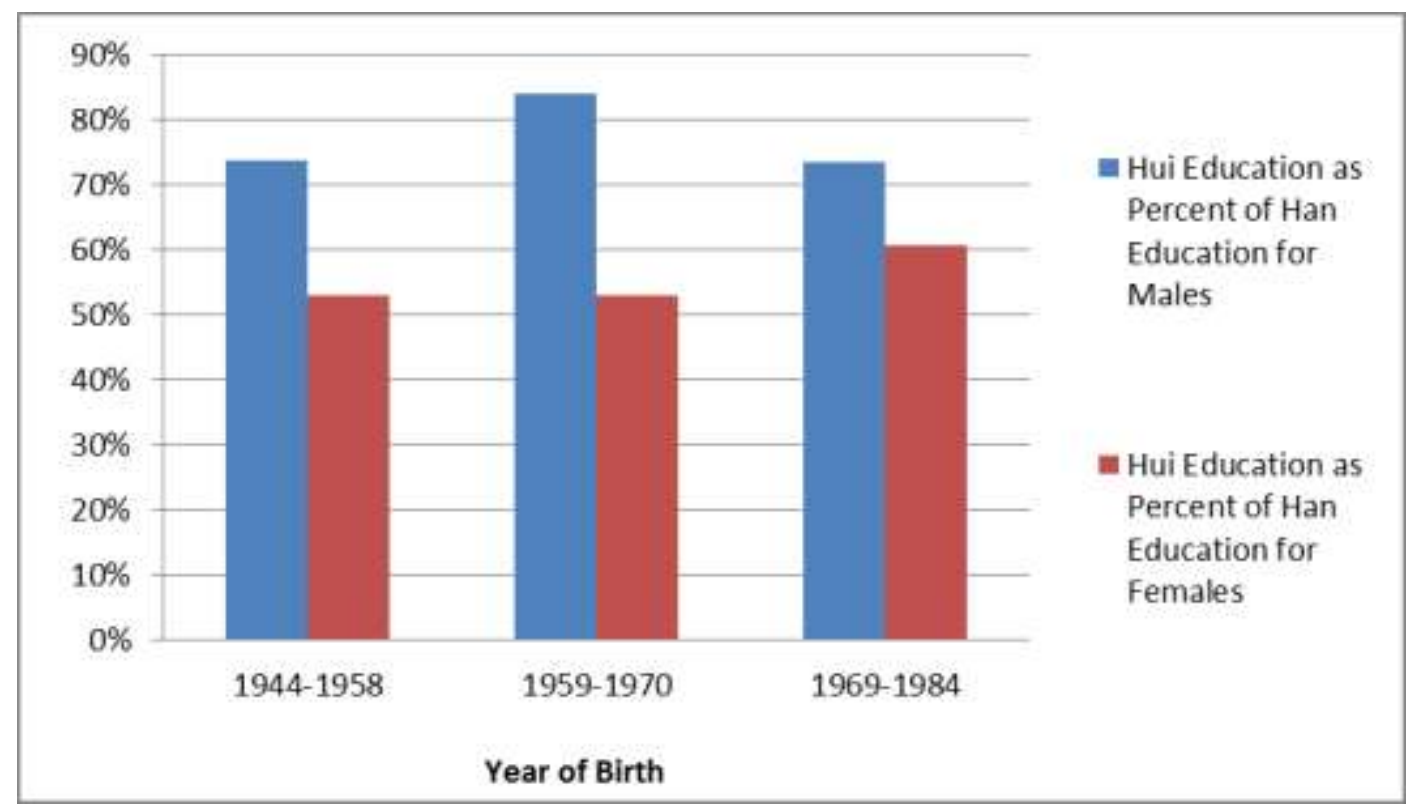

Source: Table A1 


\section{Figure 3}

Average years of schooling in urban Ningxia 2006 by birth cohort, gender and ethnicity

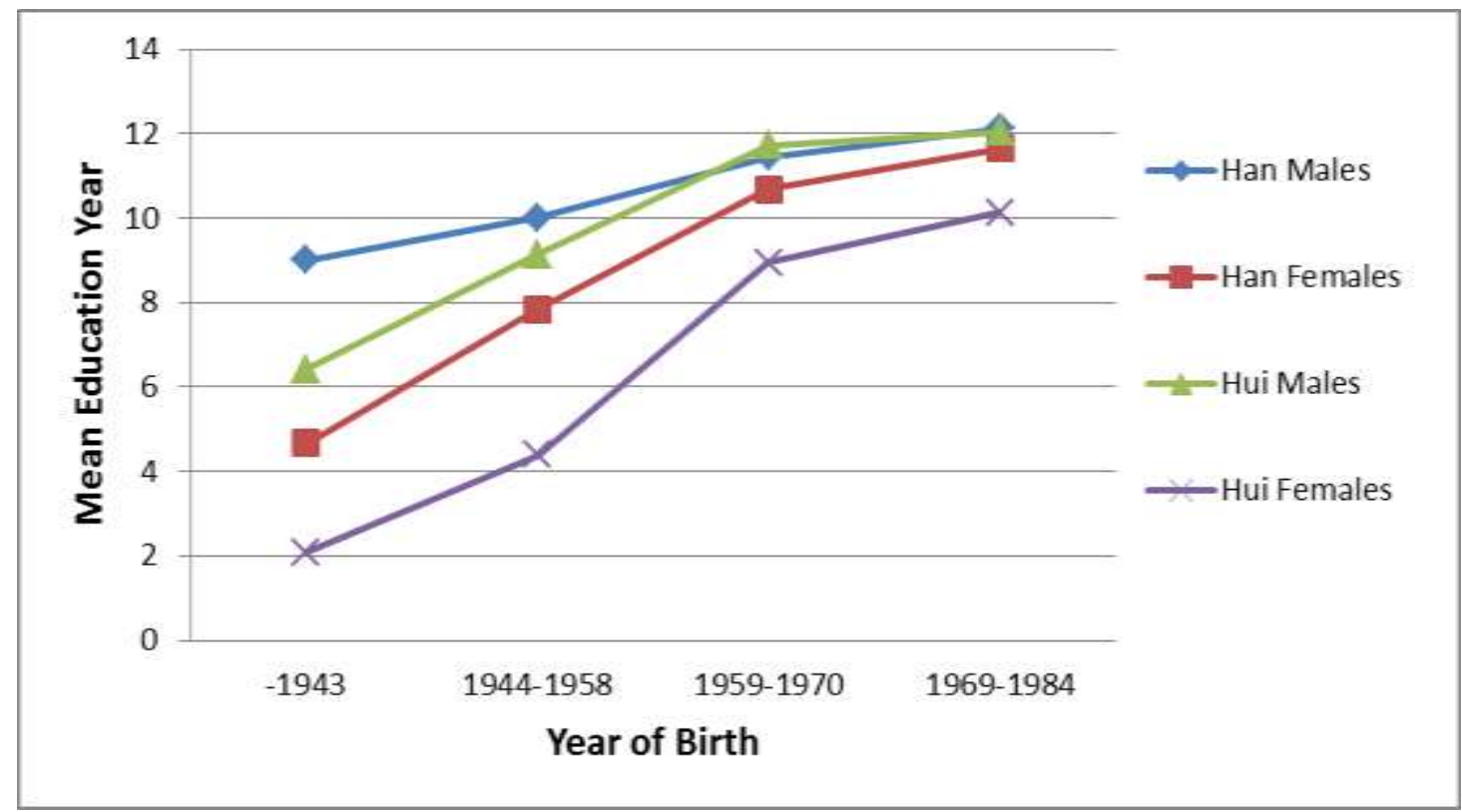

Source: Table A1 


\section{Figure 4}

Ethnicity gaps in years of schooling in rural Ningxia by birth cohort

Average years of schooling among Hui as percent of average length of schooling among Han

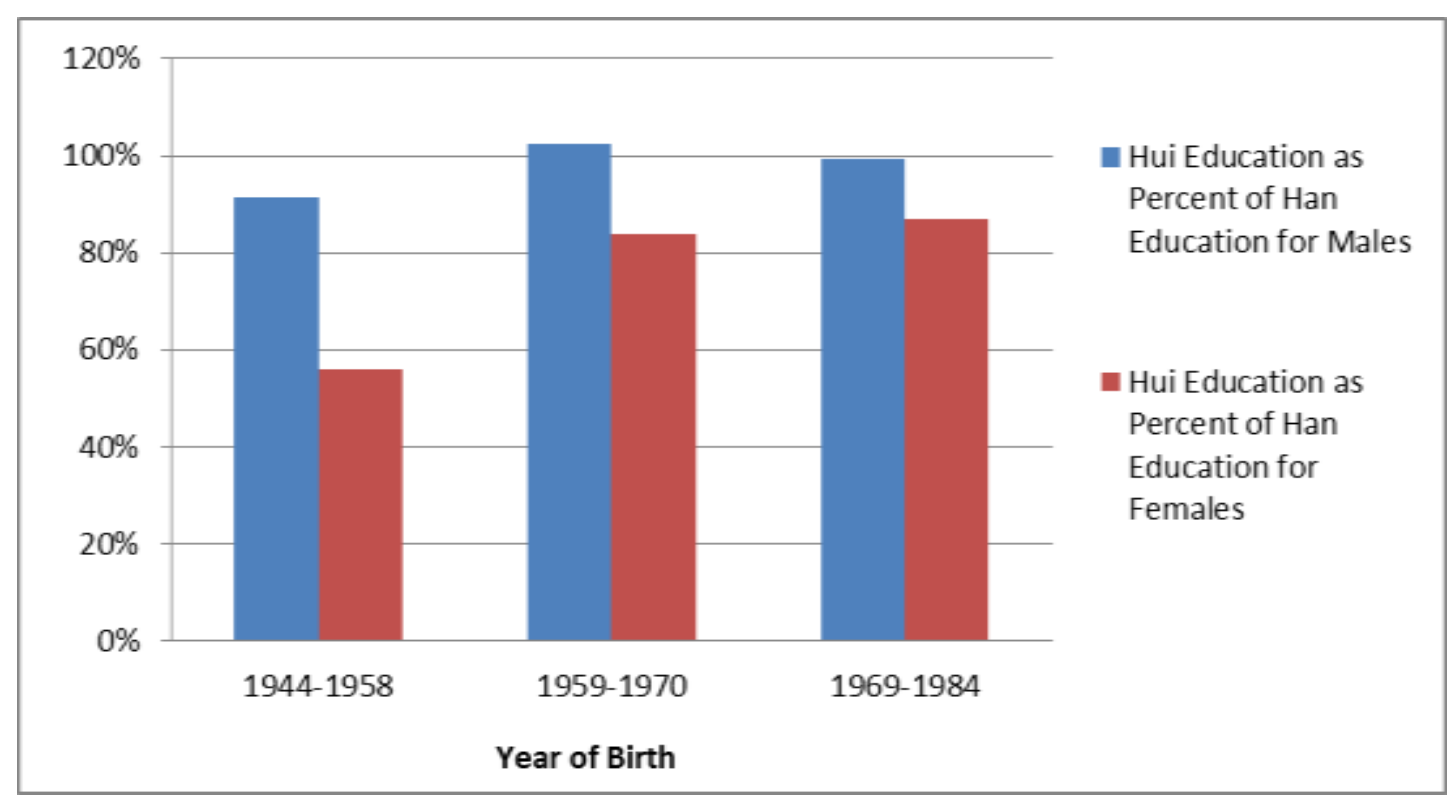

Source: Table A1 


\section{Appendix}

Table A1 Education, age, gender and ethnicity in rural and urban Ningxia 2006

\begin{tabular}{|c|c|c|c|c|c|c|c|c|c|c|}
\hline \multirow{3}{*}{$\begin{array}{l}\text { Age of } \\
\text { Person }\end{array}$} & \multicolumn{5}{|c|}{ Rural Ningxia } & \multicolumn{5}{|c|}{ Urban Ningxia } \\
\hline & \multirow{2}{*}{$\begin{array}{l}\text { Han, } \\
\text { years } \\
\text { Males }\end{array}$} & \multirow{2}{*}{$\begin{array}{r}\text { mean } \\
\text { Females }\end{array}$} & \multicolumn{2}{|c|}{ Hui, mean years } & \multirow{2}{*}{$\begin{array}{l}\text { Gini } \\
\text { coefficient }\end{array}$} & \multirow{2}{*}{$\begin{array}{l}\text { Han, } \\
\text { years } \\
\text { Males }\end{array}$} & mean & \multicolumn{2}{|c|}{ Hui, mean years } & \multirow{2}{*}{$\begin{array}{l}\text { Gini } \\
\text { coefficient }\end{array}$} \\
\hline & & & Males & Females & & & Females & Males & Females & \\
\hline $64+$ & 1.86 & 0.46 & 1.76 & 0.51 & 0.817 & 9 & 4.67 & 6.43 & 2.08 & 0.442 \\
\hline $49-63$ & 5.15 & 2.04 & 3.79 & 1.08 & 0.567 & 10.01 & 7.85 & 9.15 & 4.39 & 0.280 \\
\hline $37-48$ & 7.28 & 5.29 & 6.11 & 2.8 & 0.362 & 11.45 & 10.68 & 11.72 & 8.94 & 0.182 \\
\hline $23-36$ & 7.94 & 7.03 & 5.82 & 4.26 & 0.303 & 12.13 & 11.65 & 12.05 & 10.12 & 0.176 \\
\hline \multirow[t]{2}{*}{ 23-64+ } & 6.47 & 4.59 & 5.10 & 2.84 & 0.436 & 11.15 & 9.81 & 11.09 & 8.36 & 0.230 \\
\hline & \multicolumn{9}{|c|}{ As percent of Han males of the same age category in the same region } & \\
\hline $64+$ & 100 & 24.73 & 94.62 & 38.17 & & 100 & 51.89 & 71.44 & 23.11 & \\
\hline $49-63$ & 100 & 39.61 & 73.59 & 20.97 & & 100 & 78.42 & 91.41 & 43.86 & \\
\hline $37-48$ & 100 & 72.66 & 83.93 & 38.46 & & 100 & 93.28 & 102.36 & 78.08 & \\
\hline $23-36$ & 100 & 88.54 & 73.30 & 53.65 & & 100 & 96.04 & 99.34 & 83.43 & \\
\hline \multirow[t]{2}{*}{ 23-64+ } & 100 & 70.94 & 78.83 & 43.89 & & 100 & 87.98 & 99.46 & 74.98 & \\
\hline & \multicolumn{9}{|c|}{ Number of observations } & \\
\hline $64+$ & 88 & 97 & 52 & 41 & 278 & 74 & 59 & 14 & 13 & 160 \\
\hline $49-63$ & 246 & 210 & 146 & 121 & 723 & 126 & 136 & 33 & 36 & 331 \\
\hline $37-48$ & 333 & 326 & 189 & 200 & 1048 & 237 & 227 & 88 & 71 & 623 \\
\hline $23-36$ & 309 & 290 & 241 & 218 & 1058 & 173 & 204 & 77 & 104 & 558 \\
\hline $23-64+$ & 976 & 923 & 628 & 580 & 3107 & 610 & 626 & 212 & 224 & 1672 \\
\hline
\end{tabular}

Source: Ningxia Household Income Survey 